\title{
POTENSI ZAKAT SEBAGAI PILAR PEREKONOMIAN UMAT \\ PASCA BERLAKUNYA UU NOMOR 38 TAHUN 1999 \\ TENTANG PENGELOLAAN ZAKAT
}

(Studi Pengelolaan Zakat Di Kabupaten Kendal)

Oleh :

JA'FAR BAEHAQI

\begin{abstract}
Abstrak
Zakat merupakan salah satu lembaga jaminan sosial yang dibawa oleh Islam disamping berbagai macam sedekah. Maksud jaminan sosial adalah bahwa negara menjamin bagi setiap individu dalam negara tersebut taraf hidup yang layak. Orang fakir, sakit dan lanjut usia yang tidak lagi dapat mencapai taraf hidup ini oleh negara dijamin terwujudnya melalui zakat. Taraf hidup layak ini oleh para ahli hukum Islam diistilahkan dengan "batas kecukupan" (kifayah), untuk membedakannya dari "batas pas-pasan" (kafaf).

Zakat merupakan kewajiban agama yang harus dibayarkan oleh setiap muslim yang telah memenuhi persyaratan tertentu dalam keadaan apapun. Dàna zakat digunakan untuk membantu anggota masyarakat yang kurang benuntung. Pemikiran hukum Islam klasik-tradisional membatasi kewajiban zakat hanya pada lima jenis harta benda, yaitu membatasi hewan ternak hanya pada unta, sapi, kerbau dan kambing; dan membatasi tumbuh-tumbuhan dan buah-buahan hanya pada gandum, jelai, anggur dan kurma. UU Nomor 38 Tahun 1999 tentang Pengelolaan Zakat sudah sangat maju dalam menentukan obyek zakat. Dalam Pasal 11 ayat (2) dinyatakan bahwa harta benda yang dikenai zakat adalah (a) emas, perak dan uang; (b) perdagangan dan penusahaan; (c) hasil pertaniah, hasil perkebunan dan hasil penikanan; (d) hasil pertambangan; (e) hasil petemakan; (f) hasil pendapatan dan jasa; dan (g) rikaz. Ini artinya, hampir semua sumber perekonomian atau komoditas menjadi obyek zakat.
\end{abstract}

Kata Kunci : Pengelolaan Zakat.

\section{A. Latar Belakang Masalah}

Adalah suatu kenyataan bahwa manusia hidup saling membutuhkan satu sama lain karena secara kodrati ia tidak

\footnotetext{
* Ja'far Baehaqi, alumni Program Studi Magister Ilmu Hukum Universitas Diponegoro Periode Wisuda Juli 2005, bekerja di Fakultas Syari' ah IAIN Walisongo Semarang.
}

sempuma dan lemah ${ }^{1}$ serta pada dirinya masing-masing terdapat kekurangan yang hanya bisa dipenuhi oleh orang lain. Kekurangan yang ada pada satu orang tidak sama dengan kekurangan yang ada pada orang lain. Adanya perbedaan

1 Al-Nisa' (4) : 28. 
ini menyebabkan perbedaan dalam kemungkinan benusaha dalam mendapatkan kebutuhan hidupnya. Sebagian mendapatkan kebutuhan hidupnya secara berlebih dan sebagian yang lain mendapatkanya berkekurangan. ${ }^{2}$ Adanya kekurangan dan kelebihan dalam hal rizki tidak boleh dijadikan faktor pemisah antara sesama manusia, tetapi sebaliknya dijadikan sebab untuk saling berhubungan. Karena itu Allah memerintahkan manusia yang mendapatkan rizki berlebih memberikan bantuan kepāda mereka yang berkekurangan. Dan, dalam rangka inilah Islam mensyariatkan lembaga zakat.

Zakat merupakan salah satu lembaga jaminan sosial yang dibawa oleh Islam disamping berbagai macam sedekah. Pentingnya jaminan sosial dan perhatian Islam terhadap masalah ini bisa kita dapati dalam pidato pertama yang pernah disampaikan oleh pendiri dan kepala negara Islam yang pertama, Nabi Muhammad SAW dan juga dalam kebijakan politik yang pertama beliau ambil. ${ }^{3}$ lalah ketika

\footnotetext{
2 Al-Nahl (16) : 71 dan Al-Isra' (17) : 30.

${ }^{3}$ Pidato tersebui disampaikan di kota Medinah pada awal hijrahnya. Kata Nabi, "Wahai sekalian manusia, dahulukan bagi dirimu sekalian. Pasti kalian akan tahu, demi Allah, seorang diantara kamu akan terkejut lalu membiarkan kambingnya tiada berpenggembala. Selanjutnya Tuhan akan mengatakan kepadanya, tanpa penerjemah atau pengawal yang mengawalnya selain Dia. Tidakkah pernah datang kepadamu utusanku, lalu menyampaikan berita kepadamu. Sementara itu aku datangkan padamu harta dan aku muliakan kamu. Maka apa yang kamu dahulukan bagi dirimu?
}

Nabi mempersaudarakan kaum Muhailin (pengungsi dari Mekah) dan kaum Ansiar (penduduk asli Medinah) pada saat-saat awal beliau di Medinah. ${ }^{4}$

Maksud jaminan sosial adalah bahwa negara menjamin bagi setiap individu dalam negara tersebut taraf hidup yang layak. Orang fakir, sakit dan lanjut usia yang tidak lagi dapat mencapai taraf hidup ini oleh negara dijamin terwujudnya melalui zakat. Taraf hidup layak ini oleh para ahli hukum Islam diistilahkan dengan "batas kecukupan" (kifayah), untuk membedakannya dari "batas pas-pasan" (kafaf). ${ }^{5}$

Pada sisi lain naluri dan kecenderungan manusia untuk memiliki harta benda adalah sedemikian kuatnya, seolah-olah ia satu -dan identik- dengan naluri mempertahankan hidup. Harta benda tidak boleh dibenci dan hasrat untuk meilikinya tidak boleh dimatikan, tetapi hanyalah perlu dijinakkan

\footnotetext{
Dilihatnya oleh orang tadi ke kanan dan ke kiri, tidak terlihat sesuatu pun. Laiu dilihatnya ke depan, tak ada yang dilihatnyâ selain neraka Jahannam. Maka barang siapa dapat memelihara wajahnya dari api neraka, meskipun hanya dengan secuil kurma, lakukanlah! Dan barang siapa tidak mendapatkannya, maka ucapkanlah katakata yang baik! Dengan demikian kebaikan akan berlipat sepuluh sampai tujuh ratus kali".

${ }^{4}$ Ahmad Muhammad al- Assal dan Fathi Ahmad Abdul Karim, Sistem, Prinsip dan Tujuan Ekonomi Islam, terjemahan H. Imam Saefudin, cetakan I (Bandung : CV. Pustaka Setia, 1999), hal. 108-9.

5 Ibid., hal. 109.

6 Ali Yafie, "Islam dan Problema Kemiskinan", Pesantren, No. 2, Vol. III, Tahun 1986, hal. 3-4.
} 
dengan rasa qana'ah, yaitu rasa penghargaan untuk mensyukuri apa yang telah dimiliki yang mengarah kepada kepuasan dan rasa cinta kepada sesama. Hasrat untuk memiliki harta itu dapat pula dikendalikan dengan berinfaq, yaitu mengeluarkan atau memanfaatkan harta kepada kemaslahatan diri dan masyarakat. ${ }^{6}$ Dan, salah satu bentuk infaq itu adalah zakat, yang merupakan titik sentral dari sistem penanganan masalah kemiskinan dalam Islam.?

Sedemikian pentingnya zakat dalam Islam, maka al-Qur'an menyebutnya sampai 72 kali. $^{8}$ Demikian pula Rasulullah SAW menjelaskan bahwa zakat merupakan satu dari lima unsur bangunan keislaman. Dengan demikian, ibadah zakat menjadi diketahui secara otomatis adanya dan merupakan bagian mutlak dari keislaman. ${ }^{9}$

7 Secara garis besar dalam Islam infaq dibedakan menjadi dua : wajib dan sunnah. Infaq wajib adalah zakat, sedangkan infaq sunnah adalah shadaqah atau terkadang dipakai istilah infaq baik dengan embel-embel sunnah maupun tidak.

8 Pendapat yang lain mengatakan 82. Dalam hal ini redaksi yang dipakai antara lain al-zakah, al-shadaqah, al-ma'un, dan tha'am almiskin. Lihat Yusuf Qardhawi, Hukum Zakat : Studi Komparatif mengenai Status dan Filsafat Zakat Berdasarkan Qur'an dan Hadis, terjemahan Salman Harun, dkk., cetakan 6 (Jakarta : PT. Pustaka Litera AntarNusa, 2002), hal. 39-40.

- Ali Yafie, Menggagas Figih Sosial, cetakan 2 (Bandung : Mizan, 1994), hal. 231 dan 241. Istilah yang dipakai untuk menyebut bagianbagian keislaman seperti zakat dan yang semisalnya adalah

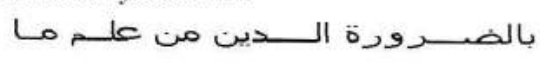

Tidak ada keraguan lagi bahwa zakat menempati kedudukan yang sangat penting dalam Islam, yaitu pada urutan kedua setelah shalat. Perintah untuk mendirikan shalat dalam al-Qur'an tidak pemah terpisahkan, melainkan selalu diikuti dengan zakat dan dengan tekanan yang sama. $^{10}$

Pembayaran zakat dinyatakan sebagai suatu tanda kualitas orang yang benarbenar beriman. Bersama dengan pengakuan keimanan, seorang beriman harus mendirikan shalat dan menuanikan zakat. Inilah yang menunjukkan arti penting keimanan seseorang kepada Allah. Orang yang menyatakan keimanannya hanya dalam kata saja, tetapi tidak membayar zakat tidak dapat dianggap sebagai muslim sejati. Setidak-tidaknya tidak ada perbuatan yang memberikan bukti keimanannya. ${ }^{11}$ Zakat merupakan kewajiban agama yang harus dibayarkan oleh setiap muslim yang telah memenuhi persyaratan tertentu dalam keadaan apapun. Dana zakat digunakan untuk membantu anggota masyarakat yang kurang beruntung. Dengan demikian, zakat membentuk masyarakat untuk bekerja sama, bertindak sebagai lembaga penjamin dan sebagai penyedia dana cadangan

\footnotetext{
(bagian-bagian keislaman yang sudah diketahui secara pasti).

10 Baca misalnya al-Baqarah (2) : 83 dan 110, alAnbiya' (21) : 73, al-Nur (24) : 56 dan lain sebagainya.

11 Afzalur Rahman, Doktrin Ekonomi Islam, Jilid III, terjemahan Soeroso dan Nastangin, cetakan
} 
bagi masyarakat yang bersangkutan. Kecuali itu, zakat merupakan lembaga jaminan sosial bagi setiap anggota masyarakat sehingga tidak seorangpun perlu merasa cemas akan masa depannya. ${ }^{12}$

Akan tetapi, dalam kenyataannya zakat seolah menjadi problem masyarakat muslim sepanjang waktu yang tiada terpecahkan hingga saat ini. Antara cita dan fakta terdapat jarak yang terlalu jauh. Antara sisi normatif dan sisi historisnya terdapat kesenjangan yang tak mampu ditutupi oleh siapapun. Potensi zakat yang demikian besar hanya sebatas potensi yang belum dapat digali secara serius karena berbagai faktor.

Dalam konteks Indonesia, tesis tersebut semakin mendapatkan pembenarannya dan menjadikannya tidak terbantahkan. Berbagai upaya telah dilakukan namun belum menunjukkan hasil yang maksimal. Tak kurang campur tangan pemerintah dalam masalah ini; dimulai dengan keluarnya Peraturan Menteri Agama RI Nomor 4 dan 5 Tahun 1968 masing-masing tentang Pembentukan Badan Amil Zakat dan Pembentukan Baitul Mal (Balai Harta Kekayaan) di tingkat Pusat, Propinsi, dan Kabupaten/Kota Madya. ${ }^{13}$ Kemudian pada tahun 1991 terbentuklah Keputusan Bersama Menteri Dalam Negeri Nomor

\footnotetext{
II (Yogyakarta : PT. Dana Bhakti Prima Yasa, 2002), hal. 246-7.

12 Ibid., hal. 248-9.
}

29 Tahun 1991 dan Menteri Agama Nomor 47 Tahun 1991 tanggal 11 Maret1991 tentang Pembinaan BAZIS. Dan pada akhimya pada tahun 1999 lahir UU Nomor 38 Tahun 1999 tentang Pengelolaan Zakat yang ditindak lanjuti dengan Keputusan Menteri Agama Nomor 581 Tahun 1999 tentang Pelaksanaan UUPZ yang kemudian diganti dengan Keputusan Menteri Agama Nomor 373 tahun 2003 tentang hal yang sama. Fenomena kesenjangan antara cita dan fakta dalam pelaksanaan zakat tersebut terjadi hampir merata di seluruh wilayah, tak terkecuali kabupaten Kendal. Penulis perlu menyebut kabupaten Kendal secara khusus karena beberapa alasan antara lain : Pertama, penulis berasal dari Kendal. Seiring dengan semangat otonomi, dalam diri penulis muncul semacam "gairah" untuk berpartisipasi lebih aktif dalam membangun dan memajukan daerah ini. Kedua, Kendal merupakan salah satu daerah yang terkenal dengan masyarakat dan kota santrinya. Adanya kesenjangan dalam pelaksanaan zakat menimbulkan rasa "penasaran" dan selanjutnya memunculkan minat untuk menelitinya. Ketiga, sumber penghasilan masyarakat Kendal sangat beragam, mulai dari yang klasik tradisional sebagaimana terdapat kesesuaian dengan kondisi di mana hukum Islam (baca : Figh) dirumuskan sampai pada sumber perekonomian modem yang benar-benar baru. 


\section{B. Rumusan Masalah}

Bertolak dari latar belakang masalah tersebut, terdapat beberapa persoalan yang perlu pembahasan lebih lanjut. Namun dalam tesis ini penulis hanya akan memfokuskan bahasan pada dua permasalahan pokok sebagai berikut :

1. Bagaimanakah potensi zakat digali dan dimujudkan di Kabupaten Kendal?

2. Faktor-faktor apa saja yang berpenganuh terhadap upaya penggalian potensi zakat di Kabupaten Kendal, baik yang menunjang maupun yang menghambat?

3. Bagaimanakah potensi zakat sebagai pilar perekonomian umat di Kabupaten Kendal?

C. Kerangka Teori dan Pemikiran Penentuan obyek zakat didasarkan pada petunjuk wahyu, yakni al-Qur'an dan Hadits. Dalam hal ini al-Qur'an hanya menentukan secara umum dan garis besarnya saja, sedangkan penjelasan dan rinciannya diberikan oleh Hadits. Berikut ini lima jenis harta benda yang dikenai kewajiban zakat sebagaimana dimaksud, yaitu :

1.Tumbuh-tumbuhan dan buah-buahan yang secara umum ditunjuk dalam ayat 267 surat al-Baqarah ${ }^{14}$ dan detailnya

\footnotetext{
13 M. Daud Ali dan Habibah Daud, Lembaga-lembaga Islam di Indonesia, cetakan I (Jakarta : PT. Raja Grafindo Persada, 1995), hal. 254.

14 Bunyi ayat dimaksud adalah :

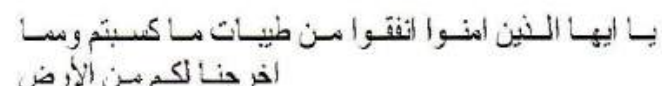

dikemukakan dalam hadits riwayat alThabrani dan al-Hakim; ${ }^{15}$

2.Hewan temak ditunjuk secara rinci dalam hadits Bukhari; ${ }^{16}$

3.Emas dan perak secara otentik dan global dijelaskan dalam ayat 34-35 surat al-Taubah $^{17}$ sedangkan secara rinci dijelaskan dalam hadits Abu Dawud; ${ }^{18}$

15 Teks selengkapnya sebagai berikut :

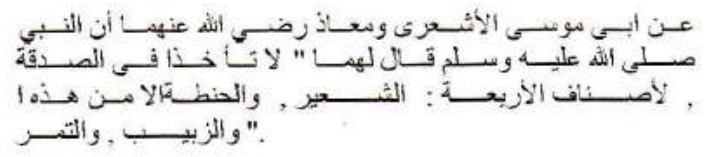

Baca, misalnya, Al-Hafidz Ibn Hajar al-'Asqalaniy, Bulugh al-Maram min Adillah al-Ahkam (Indonesia : Dar Ihya al-Kutub al'Arabiyyah, t.t.), hal. 122.

16 Hadits ini sangat panjang sekali dan baiklah saya kutipkan sebagian dari teksnya berikut ini:

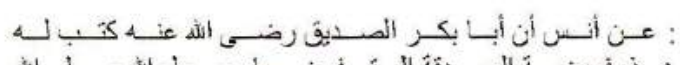

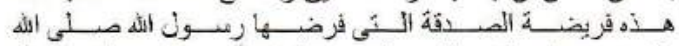

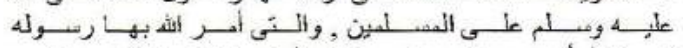

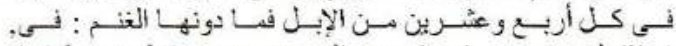

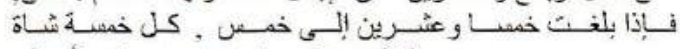

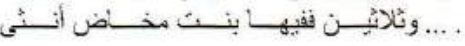

Baca Ibid., hal. 118-119 dan Sulaiman al-Nuriy, Ibanah al-Ahkam Syarh Bulugh al-Maram, Juz II (Bairut : Dar al-Tsaqafah al-Islamiyyah, 1.1.), hal. 283-288.

17 Berikut ini bunyi kedua ayat tersebut :

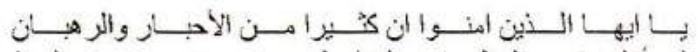

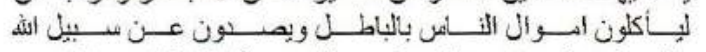

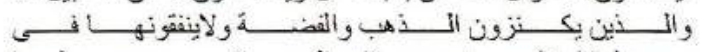

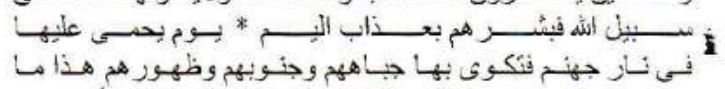

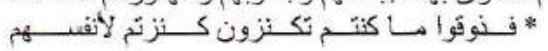

18 Berikut teks hadits dimaksud :

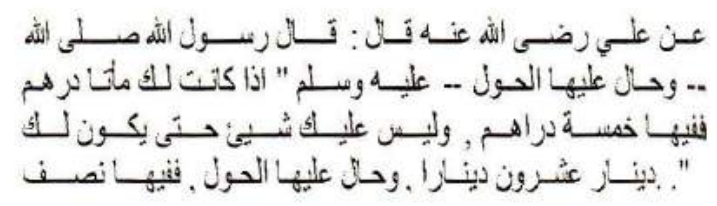

Al-Hafidz., Ibid., hal. 121. 
4. Harta benda yang diperdagangkan (mal al-tijarah) secara umum patokannya dijelaskan dalam ayat 267 surat alBaqarah, sedangkan secara rinci antara lain dijelaskan dalam hadits riwayat Abu Dawud; ${ }^{19}$

5. Harta benda yang ditemukan dari perut bumi (barang tambang) kecuali secara umum ditunjuk dalam ayat 267 surat al-Baqarah, juga secara rinci dikemukakan dalam hadits, antara lain hadits riwayat Bukhari dan Muslim. ${ }^{20}$

Pemikiran hukum Islam klasiktradisional membatasi kewajiban zakat hanya pada lima jenis harta benda tersebut. Begitu pula, macam dari masing-masing jenis dimaksud dibatasi sebagaimana yang tersebut dalam teks suci. Keterpakuan tekstual, dalam hal ini, membuat para pemikir klasik membatasi hewan ternak hanya pada unta, sapi, kerbau dan kambing; dan membatasi tumbuh-tumbuhan dan buah-buahan hanya pada gandum, jelai, anggur dan kurma. ${ }^{21}$

19 Berikut bunyi teksnya :

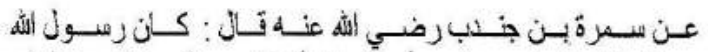

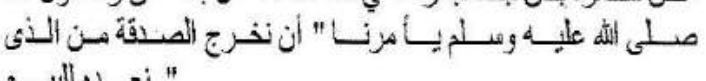

Ibid., hal. 124 .

20 Ibid. Berikut ini teksnya :

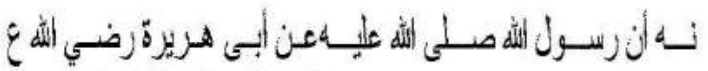

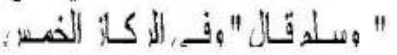

21 Baca, misalnya, Abdurrahman al-Jaziriy, Al-Figh 'ala al-Madzahib al-Arba'ah, Juz II (Istambul Turki : Maktabah al-Haqiqah, 1986), hal. 596.
Sebenarnya para pendahulu dan pemuka madzhab hukum Islam telah berpikir maju ketika mereka memperluas pengertian obyek zakat dari sekedar yang telah ditunjuk secara rinci oleh teks suci. Imam Abu Hanifah, misalnya, memasukkan kuda ke dalam kelompok ternak yang dikenai kewajiban zakat. Demikian pula sahabat Umar. $^{22}$ Imam Malik dan imam Syafi'i memperluas cakupan obyek zakat dari jenis tumbuhtumbuhan dan buah sampai kepada semua hasil tumbuh-tumbuhan yang bisa dijadikan makanan pokok dan punya daya tahan untuk disimpan. Bahkan Abu Hanifah mengembangkannya lebih luas lagi sampai kepada semua hasil bumi, selain kayu bakar dan bambu. Namun sayang, upaya kreatif nan cerdas itu oleh orang-orang sesudah mereka tidak mendapatkan apresiasi lebih lanjut dengan lebih mengembangkannya lagi. Agaknya, budaya keterikatan penuh pada satu madzhab hukum tertentu merupakan kuncinya. Budaya ini berakibat tidak diacuhkannya pemikiran maju dari madzhab lain. Demikian pula, tidak jarang terjadi upaya kreatif sebagaimana tersebut di atas dianggap sebagai hasil pemikiran final, sehingga tidak perlu (dan tidak boleh?) diubah dan dikoreksi lagi.

22 Al-Imam al-Qadhi Abu al-Walid Muhammad bin Ahmad bin Ahmad Bin Rusyid al-Qurthubi al-Andalusiy, Bidayah al-Mujtahid wa Nihayah al-Muqtashid, Juz I (ttp. : Dar alFikr, t.t.), hal. 183 . 
UU Nomor 38 Tahun 1999 tentang Pengelolaan Zakat (selanjutnya disebut Undang-undang Pengelolaan Zakat atau disingkat UUZ) sudah sangat maju dalam menentukan obyek zakat. Dalam Pasal 11 ayat (2) dinyatakan bahwa harta benda yang dikenai zakat adalah (a) emas, perak dan uang; (b) perdagangan dan perusahaan; (c) hasil pertanian, hasil perkebunan dan hasil perikanan; (d) hasil pertambangan; (e) hasil petemakan; (f) hasil pendapatan dan jasa; dan (g) rikaz. Ini artinya, hampir semua sumber perekonomian atau komoditas menjadi obyek zakat.

Perluasan obyek zakat merupakan tuntutan logis. Betapa tidak, sumber perekonomian pada saat ini telah mengalami kemajuan yang pesat, jauh berbeda dengan situasi pada saat teks-teks suci diturunkan. Demikian pula, sumber-sumber perekonomian di Millenium Ketiga ini telah berkembang pesat dibanding dengan masamasa para imam madzhab, saat dimana fiqh dirumuskan. Bila demikian halnya, bagaimana mungkin zakat akan menemukan fungsi sosial dan ekonominya bila obyeknya hanya komoditas-komoditas tertentu saja? Bagaimana mungkin zakat dapat bertindak sebagai alat khas yang diberikan oleh Islam untuk mengahapuskan (baca : mengurangi) kemiskinan di tengah masyarakat bila sumber pendanaannya hanya itu-itu saja? Dan bagaimana mungkin zakat akan mampu mencegah penumpukan kekeayaan yang mengerikan dalam tangan segelintir orang dan memungkinkan kekayaan tersebut disebarkan sebelum sempat menjadi besar dan sangat berbahaya di tangan para pemliknya apabila ia hanya mencakup jenis kekayaan tertentu saja? $^{23}$

Sumber dana yang tetap dan besar melalui zakat sebagaimana diinginkan tidak akan mungkin tercapai dan atau tidak akan tepat mengenai sasaran apabila pelaksanaan zakat diserahkan kepada kemauan para wajib zakat saja. Peranan organisasi dan kekuasaan yang mengatur dan mengayomi diperlukan juga, yaitu dengan adanya amilin dan imam yang aktif dalam menjalankan dan mengatur pelaksanaan sistemnya. $^{24}$

Ada beberapa akibat negatif apabila zakat diserahkan kepada kemauan para wajiba zakat, antara lain :

1. Para wajib zakat yang belum mantap kesadaran beragamanya, atau mempunyai sikap mental egoistis dan materialistis tidak akan tergugah hati nuraninya untuk menolong sesama manusia yang

23 Untuk diskusi lebih lanjut tentang hal ini baca, misalnya, M. Abdul Mannan, Teori dan Praktek Ekonomi Islam, terjemahan M. Nastangin (Yogyakarta : PT. Dana Bhakti Wakaf, 1997), hal. 256.

24 KH. Ali Yafie, "Islam dan Problema Kemiskinan", Pesantren, No. 2, Vol. III, Tahun 1986, hal. 8. 
memerlukan uluran tangannya melalui kewajiban zakat;

2. Fakir miskin dan mustahiq lainnya yang tahu harga diri secara psikologis merasa lebih terhormat (tidak merasa malu, segan atau tersinggung persaannya), apabila mereka menerima zakat dari panitia/pemerintah daripada menerimanya secara langsung dari wajib zakat;

3. Distribusi zakat tidak merata kepada mustahiqin, apalagi sampai ke 8 ashnafjalur yang berhak menerimanya, tidak efisien dan tidak pula efektif dan produktif, sehingga tidak tercapai tujuan/ sasaran utama dari zakat. ${ }^{25}$

Fungsi amil zakat adalah sebagai penghubung antara wajib zakat dan yang berhak menerima zakat; ia berkewajiban menyampaikan harta zakat yang diterimanya itu kepada yang berhak dengan cara yang tepat dan terarah sesuai dengan tujuan disyariatkannya zakat. Dengan telah diserahkannya zakat kepada amil, wajib zakat telah terlepas dari kewajibannya. Harta zakat yang diserahkan oleh wajib zakat kepada amil merupakan amanah yang wajib dipegang teguh dan dipertanggung jawabkannya. Amil harus berbuat sebaik mungkin sehingga dana

\footnotetext{
25 Masjfuk Zuhdi, Masail Fighiyah, Edisi II Cetakan II (Jakarta : CV Haji Masagung, 1991), hal. 224.
}

zakat tersebut mencapai daya guna yang maksimal. $^{26}$

Melakukan penarikan zakat dengan hasil yang maksimal merupakan suatu kesulitan. Akan tetapi tidak kalah sulitnya adalah melakukan pembagian atau pentasharupan dana zakat. Dalam persolan ini, pengelola zakat dihadapkan pada ketentuan normatif yang menghendaki pemerataan pada semua mustahiq dan tuntutan realitas plus keadilan sosial yang menghendaki dana zakat diberikan pada orang atau pihak yang benar-benar membutuhkan secara ekonomis, sehingga zakat mempunyai arti sosial secara maksimal. $^{27}$

Secara umum penulis setuju pada pilihan pertama, namun dalam kondisikondisi tertentu penulis lebih condong pada pilihan kedua. Alternatif pertama didasarkan pada ayat 60 surat al-Taubah. Sedangkan alternatif kedua lebih mengacu pada pemahaman hadits Nabi tatkala beliau mengatakan kepada Mu'adz bin Jabal yang saat itu beliau tugaskan ke

\footnotetext{
26 Ibid., hal. 197.

27 Persoalan ini telah ada sejak dahulu ketika fiqh dirumuskan. Al-Sayyid Abi Bakr bin al-Sayyid Muhammad Syatha al-Dimyati, misalnya, menuturkan adanya perbedaan dalam hal ini. Menurut syafi'iyyah, pemerataan pada semua mustahiq adalah wajib, Sedangkan menurut selain syafi'iyyah pemerataan itu tidak wajib. Karena itu boleh menyerahkan harta zakat pada satu mustahiq saja. Lebih lanjut baca Al-Sayyid Abi Bakr bin al-Sayyid Muhammad Syatha al-Dimyati, I'anah alThalibin, Juz II (Semarang : Maktabah wa Mathba'ah Thoha Putra, t.t.), hal. 187.
} 
Yaman, "Ajarkan kepada mereka bahwa mereka dikenakan zakat, yang diambil dari orang kaya dan diberikan kepada golongan miskin". ${ }^{28}$ Perlu dijelaskan di sini bahwa hal ini tidak berarti ada pertentangan antara dua nash tersebut. Agaknya lebih bijak bila nash kedua, yakni Hadits Mu'adz diposisikan sebagai mukhashshish. Artinya, Nash al-Qur'an itu bersifat umum, sedangkan nash Hadits bersifat khusus. Atau, nash Hadits hanya memberikan penekanan saja pada golongan fakir dan miskin oleh karena sasaran pertama zakat adalah menghapuskan kemiskinan dan kemelaatan dalam

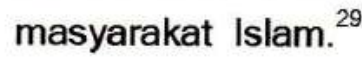

\section{Metode Penelitian}

\section{Metode Pendekatan}

Metode pendekatan pada penelitian ini menggabungkan antara pendekatan yuridis normatif dan pendekatan yuridis sosiologis. ${ }^{30}$ Pendekatan yuridis normatif terutama dipergunakan dalam mengungkapkan kaidah-kaidah normative yang terdapat dalam hukum Islam yang bersumberkan al-Qur'an dan as-Sunnah, peraturan-peraturan perundang-undangan yang ada mengenai zakat dan pelaksanannya maupun bahan-bahan lain yang terkait, baik dari sumber-sumber

\footnotetext{
28 Sebagaimana dikutip Yusuf Qardhawi, Op. cit., hal. 510. Bunyi teksnya senada dengan teks Hadits yang terdapat dalam catatan kaki nomor 31
}

yang didokumentasikan maupun informasi lisan dari narasumber yang menguasai bidang ini.

Pendekatan yuridis sosiologis sebagai pendekatan utama dalam penelitian ini digunakan untuk menggali informasi tentang zakat dan pelaksanaannya di wilayah Kendal, terutama yang berkaitan dengan wajib zakat, obyek zakat, cara pembayaran zakat, dan pengelolaan zakat oleh badan/ lembaga pengelola.

\section{Spesifikasi Penelitian}

Penelitian ini bersifat deskriptif analitis, yaitu memaparkan, menggambarkan atau mengungkapkan hukum Islam, peraturan perundangan, maupun bidang kajian lain yang terkait, yang berkenaan dengan zakat dan pengelolaannya, dalam hal eksistensi dan relevansinya dalam dan dengan kehidupan masyarakat.

\section{Sumber dan Metode Pengumpulan Data}

\footnotetext{
30 Dalam bahasa Soetandyo Wignyosoebroto pendekatan yang dipakai di sini sekaligus memadukan pendekatan doktrinal dan pendekatan non-doktrinal. Soetandyo Wignyosoebroto, "Keragaman dalam Konsep Hukum, Tipe Hukum dan Metode Penelitiannya", makalah disampaikan Pelatihan Peneliti Tenaga Edukatif IAIN Walisongo tanggal 1 Oktober s/d 27 Desember 1996, terutama hal. 5-9 dan 1117. Atau, menurut istilah Ritzer, disebut penelitian yuridis-empiris (penelitian terpadu dengan paradigma ganda). George Ritzer, Sosiologi Ilmu Pengetahuan Berparadigma Ganda, Alimandan (Penyadur), (Jakarta : Rajawali Pers, 1992), hal. 174-5.
} 
Data yang akan dikumpulkan dalam penelitian ini dapat digolongkan menjadi dua, data primer dan data sekunder. Data primer berupa informasi yang langsung didapatkan dalam penelitian lapangan. Data ini diperoleh melalui wawancara, penyebaran angket dan pengamatan di lapangan. Wawancara dilakukan terhadap wajib zakat, pengelola zakat dan tokoh masyarakat/kiyahi. Data sekunder adalah data yang diperlukan untuk melengkapi data primer. Data sekunder ini diperoleh dengan melihat pada laporan-laporan pengelolaan zakat dari lembaga pengelola yang terdokumentasikan dan literatur-literatur yang relevan dengan penelitian ini.

\section{Populasi dan Penentuan Sampel}

Populasi dalam penelitian ini adalah orang-orang yang terlibat (baca: aktif) dalam badan/lembaga pengelola zakat, masyarakat wajib zakat dan tokoh masyarakat/kiyahi yang ada di wilayah Kabupaten Kendal. Dalam penelitian ini sampel ditentukan melalui pusposive sampling, yakni ditentukan berdasarkan tujuan tertentu dengan melihat pada persyaratan-persyaratan antara lain : didasarkan pada ciri-ciri, sifat-sifat atau karakteristik tertentu yang merupakan ciriciri utama dari obyek yang diteliti dan penentuan karakteristik populasi dilakukan dengan teliti melalui studi pendahuluan. ${ }^{31}$

Sehubungan dengan hal tersebut, maka akan dipilih tiga wilayah kecamatan yang ada di Kabupaten Kendal, yaitu Kecamatan Kota Kendal, Kecamatan Ngampel, dan Kecamatan Patebon. Kemudian secara bertingkat dari masingmasing kecamatan tersebut akan diambil tiga desa yang dianggap dapat menggambarkan adanya beberapa atau sebagian dari kriteria di atas.

\section{Metode Analisa Data}

Data yang terkumpul sebagaimana dimaksud di atas kemudian diidentifikasi dan dikategorikan dalam suatu sistematika tertentu, selanjutnya dianalisis dengan menggunakan metode analisis kualitatif sekaligus analisis kuantitatif. Data tentang mekanisme kerja badan/lembaga pengelola zakat dijadikan satu kategori, demikian pula data tentang cara masyarakat berzakat, persepsi terhadap zakat dan badan/lembaga pengelola zakat, kesadaran berzakat, dan lain-lain. Karakteristik datanya yang

\footnotetext{
31 Sebutan purposive menunjukkan bahwa teknik ini digunakan untuk mencapai tujuan-tujuan tertentu. Namun sebenarnya, semua sampling pasti bertujuan, tidak hanya model purposive saja. Karena itu sebutan pusposive sampling untuk suatu teknik sampling sebenarnya tidak tepat. Akan tetapi oleh karena tidak atau belum ada sebutan lain yang lebih jitu untuk menggambarkan teknik yang dimaksudkan, maka sebutan ini masih dipakai. Selengkapnya baca Sutrisno Hadi, Metodologi Research, Jilid I, Cetakan X (Yogyakarta : Yayasan Penerbitan Fakultas Psikologi UGM, 1980), hal. 82-83. Juga baca, misalnya, Setya Yuwana Sudikan. Penuntun Penyusunan Karya Ilmiah. cetakan ke 2 (Semarang : CV. Aneka Ilmu, 1986), hal. 34 .
} 
berbentuk kata verbal menjadikannya memerlukan olahan sejak dari menuliskan hasil observasi, wawancara atau rekaman, mengedit, mengklasifikasi, mereduksi, dan menyajikannya secara sistematis. ${ }^{32}$ Dengan kata lain, analisis dilakukan tenus menerus sejak proses pengumpulan data hingga penyajiannya. Dan tentu saja, analisis dilakukan dengan mengacu pada kerangka teori dan pemikiran seperti tersebut di atas. Dari hasil analisis tersebut kemudian ditarik kesimpulan yang pada dasarnya merupakan jawaban atas permasalahan yang diangkat dalam penelitian ini.

\section{E. Hasil Penelitian}

Terdapat banyak badan/lembaga pengelola zakat di Kabupaten Kendal. Akan tetapi kebanyakan badan/lembaga tersebut bukan menupakan badan/lembaga yang permanen dan tetap. Keberadaannya bersifat musiman, kepengurusan dibentuk seadanya, tidak ada aturan main organisasi yang jelas, tidak punya kantor atau alamat, serta tidak berbadan hukum. Badan/lembaga pengelola zakat di Kabupaten Kendal yang layak dan relevan untuk studi ini hanya ada empat yaitu Badan Anmil Zakat Kabupaten Kendal (selanjutnya

\footnotetext{
32 Baca, misalnya, Noeng Muhajdir, Metodologi Penelitian Kualitatif, edisi III, cetakan 8 (Yogyakarta : Rake Sarasin, 1998), hal. 29. ${ }^{33}$ Petunjuk Pelaksanaan Pembinaan Lembaga Pengelola Zakat (Jakarta : Direktorat Pengembangan Zakat dan Wakaf Direktorat Jenderal Bimbingan Masyarakat Islam dan Urusan Haji, 2003), hal. 128-129.
}

disebut BAZ Kendal), Badan pelaksana urusan zakat Muhammadiyah (Bapelurzam) Cabang Weleri, Lajnah Amil Zakat, Infaq dan Shadaqah (Lazis) NU Kabupaten Kendal, dan Badan pelaksana zakat, infaq dan shadaqah (Bapelazis) Kantor Departemen Agama Kabuapten Kendal (selanjutnya disebut Bapelazis saja).

1. Penggalian Potensi Zakat di Kabupaten Kendal

Dari perspektif manajemen pengelolaan, pranata zakat mempunyai dua sisi utama yaitu pengumpulan dan penyaluran. Pengumpulan zakat antara lain ditempuh dengan langkah sebagai berikut : (i) muzakki secara langsung datang kepada BAZルLZ, (ii) melalui counter zakat, (iii) melalui UPZ, (iv) melalui pos, (v) melalui bank, (vi) melalui pemotongan gaji, dan (vii) melalui pemotongan pajak. Sedang penyaluran zakat dilaksanakan dengan memperhatikan beberapa hal antara lain : adanya dua pos utama yaitu pendistribusian dan pendayagunaan, penekanan pada kelangsungan hidup fakir miskin, penekanan pada upaya pembinaan umat Islam, dan penekanan pada upaya pemberdayaan ekonomi umat. $^{33}$

\section{a. Pengumpulan Zakat}

Konsisten dengan pembahasan di atas, sub bahasan ini hanya akan memeparkan apa yang di Bapelurzam dan Bapelazis. Karena hanya dua lembaga pengeloa itu yang dapat beroperasi. 
Meskipun Bapelurzam adalah milik persyarikatan Muhammadiyah akan tetapi tidak hanya warga Muhammadiyah saja yang mempercayakan zakatnya pada Bapelurzam. Dalam kenyataannya tidak sedikit warga NU yang menitipkan zakatnya pada Bapelurzam, meskipun di NU sendiri ada lembaga amil yaitu Lazis NU. Memang data tentang warga NU yang berzakat pada Bapelurzam ini tidak bersifat tertulis, namun bersumber semata dari pengurus Bapelurzam. Dan, memang dalam daftar nama muzakki yang dirilis Bapelurzam tidak menyebutkan ormas yang diikuti oleh para muzakki. Artinya data itu tidak menyebutkan apakah muzakki itu warga NU atau Muhammadiyah.

Meskipun diakui oleh eksponennya belum berhasil, Bapelurzam Weleri beberapa langkah cukup maju bila dibandingkan dengan organisasi pengelola zakat yang lain terutama yang ada di Kabupaten Kendal. Penilaian itu secara mudah saja dapat dilakukan berdasarkan pada jumlah dana zakat yang berhasil dikumpulkan. Pada tahun zakat 1425 H / 2005 M Bapelurzam Weleri berhasil mengumpulkan dan mengelola dana zakat sebesar Rp. 278.950.000,- (dua ratus tujuh puluh delapan juta sembilan ratus lima puluh ribu rupiah) atau naik ,13 persen dari tahun zakat sebelumnya yaitu Rp. 247.000.000,- (dua ratus empat puluh tujuh juta rupiah). Sementara itu secara keseluruhan dana yang berhasil dikumpulkan dan dikelola
Bapelurzam se Kabupaten Kendal pada tahun $1425 \mathrm{H} / 2005 \mathrm{M}$ adalah 702.988.650,- (tujuh ratus dua juta sembilan ratus delapan puluh delapan ribu enam ratus lima puluh rupiah). ${ }^{34}$

Agaknya, ada beberapa "kejanggalan" berkaitan dengan konsepsi yang dipilih dan strategi yang diterapkan oleh Bapelurzam dalam hal pengelolaan zakat terutama dari sisi pengumpulan ini. Pertama, obyek zakat tidak dirinci menurut bidang atau jenisnya. Ketika para muzakki menyerahkan zakatnya pengurus tidak menanyakan jenis harta yang dizakati dan karena itu pula dalam tanda terima setoran zakat tidak ada klausul jenis harta. Yang demikian karena Bapelurzam Kendal (dan Muhammadiyah?) berpendapat bahwa zakat dipungut dari "amwal" artinya seluruh kekayaan atau istilahnya harta terpadu, bukan hanya dari harta kekayaan tertentu. Jelasnya, semua jenis harta harus dizakati. Tidak ada harta kekayaan yang terbebas dari pensucian atau pemutihan oleh zakat. Konsepsi zakat sektoral seperti pertanian, peternakan, perhiasan, perdagangan, barang tambang, barang temuan/harta karun, dan profesi, demikian Bapelurzam, merupakan bagian dari sumber kemacetan pengamalan zakat. ${ }^{35}$

\footnotetext{
34 Lembaga Amil Zakat "Badan Pelaksana Urusan Zakat Zakat Muhammadiyah" (Bapelurzam) Daerah kendal, Laporan Zakat Tahun 1425 H, hal. 5 .

${ }^{35}$ Zakat Kita Zakat Terapan Buku I, (Kendal : Pengurus Daerah Muhammadiyah Kabupaten Kendal, 1999), hal. 4-5.
} 
Kedua, tidak dipakainya standar atau batasan (nishab) harta kekayaan sebagaimana lazimnya. Dalam hal ini Bapelurzam mengeluarkan aturan nishab tersendiri yang lain daripada yang lain. Peraturan nishab yang digunakan oleh Bapelurzam adalah kekayaan terpadu dikurangi hutang terpadu sama dengan plus. Betapapun plusnya hanya Rp. 1.000,(seribu rupiah) saja harus dikeluarkan zakatnya sebesar 2,5 persen. Lebih jelasnya berikut ini aturan nishab ala Bapelurzam.

$\mathrm{k}-\mathrm{h}=+$ (kekayaan terpadu dikurangi hutang terpadu sama dengan sisa plus), maka memenuhi kriteria nishab (kaya/mampu) dan wajib zakat;

$\mathrm{k}-\mathrm{h}=0 \quad$ (kekayaan terpadu dikurangi hutang terpadu sama dengan nol/tidak memiliki kekayaan), maka tidak memenuhi kriteria nishab dan karenanya tidak wajib zakat. Bahkan bila perlu dapat diberi zakat sebagai peringkat kedua;

$\mathrm{k}-\mathrm{h}=-\quad$ (kekayaan terpadu dikurangi hutang terpadu sama dengan minus), maka termasuk fakir miskin/dlu'afa dan berhak menerima santunan/dana bimbingan ekonomi. ${ }^{36}$

Konsekwensi dari aturan nishab tersebut, sebagaimana tercemin dalam daftar nama

\footnotetext{
${ }^{36}$ Ibid., hal. 5 dan 11
}

muzakki, banyak sekali ditemukan besaran zakat yang dibayarkan di bawah Rp. 50.000 ,- (lima puluh ribu nupiah). ${ }^{37}$ Dalam hal ini diantara para muzakki itu terdapat para tukang becak. ${ }^{38}$

Ketiga, sebagai konsekwensi dari "kejanggalan" yang pertama kadar zakat ditentukan secara pasti 2,5 persen dari kekayaan murni tanpa melihat jenis harta kekayaan tersebut.

Keempat, cara menghitung kekayaan oleh Bapelurzam ditentukan sebagai berikut: Kekayaan baru / belum pernah dizakati pada tahun yang lalu dihitung 100 persen. Kekayaan yangselalu berubah/beredar seperti barang dagangan, bahan maupun hasil produksi dan lain-lain dinilai sebagai kekayaan baru;

Kekayaan lama adalah kekayaan yang sudah pemah dizakati dan tidak pemah berubah dihitung nilai atau harga jasanya semacam sewa saja. Rumah hasil rehabilitasi dihitung nilai sewa ditambah biaya rehab. Harta lama yang harganya cukup tinggi dianjurkan untuk dinilai jasa sewanya ditambah sedikit sebagai bentuk kehati-hatian (lil ihtiyath);

\footnotetext{
${ }^{37}$ Baca, misalnya, Badan Pelaksana Urusan Zakat Muhammadiyah (Bapelurzam) Cabang Weleri, Laporan Pengelolaan Zakat Amwal Periode XXVII Tahun $1425 \mathrm{H} / 2005 \mathrm{M}$, hal. $4-24$.

${ }^{38}$ Wawancara dengan Pengurus Bapelurzam.
} 


\begin{abstract}
Penghasilan baru seperti gaji atau honor yang sebagaian besar habis untuk kebutuhan hidup harian yang wajar dihitung kenyataan sisanya yang menjadi kekayan meskipun tidak berujud uang, misalnya sudah berupa meubeler, kendaraan, perhiasan, biaya rehab baru dan lain-lain. ${ }^{39}$
\end{abstract}

Para muzakki diharapkan dapat menghitung sendiri kekayaan dan zakatnya dengan mengacu pada ketentuan di atas. Namun demikian, Bapelurzam terutama petugas operasional bisa membantu memberikan tuntunan tentang cara penghitungan harta kekayaan dan zakatnya.

\section{Kelima, zakat (warga} Muhammadiyah) harus kepada amilin (baca : Bapelurzam). Memberikan zakat secara langsung kepada mustahiqin, menurut Bapelurzam, tidak sah. Yang demikian itu bukan zakat, tetapi shadaqah atau lainnya misalnya promosi. ${ }^{40}$

Strategi pengelolaan zakat progressif tersebut agaknya didorong oleh cita-cita akan terlaksananya pranata zakat secara sukses. Karena itu seluruh perangkat baik keras maupun lunak hanus dipersiapkan secara matang termasuk pemilihan konsepsi-konsepsi progressif tadi. Menurut Bapelurzam, semua aturan zakat yang berakibat pada kegagalan dan kemacetan realisasi zakat adalah batal walaupun

\footnotetext{
39 Zakat Kita., Op cit., hal. 11.

${ }^{40}$ Ibid., hal. 6 dan 11.
}

dikatakan berdasar ayat al-Qur'an dan as-Sunnāh. Ayat al-Qur'an dan as-Sunnah yang diambil pastilah tidak relevan karena terjadi kesalahan dalam penginterpretasiannya. ${ }^{41}$

Lair Bapelurzam, lain pula Bapelazis. Pengumpulan zakat oleh Bapelazis tidak begitu menemui kendala berarti seperti yang dihadapi oleh Bapelurzam. Demikian pula strategi dan konsepsi-konsepsi perzakatan yang di dipakai oleh Bapelazis tidak seradikal yang dipakai oleh Bapelurzam. Strategi dan konsepsi yang dipakai oleh Bapelazis terkesan konvensional dan datar-datar saja untuk ukuran saat ini. Yang demikian kecuali karena para wajib zakat di Bapelazis cenderung homogin (PNS), pun pula mereka terikat dengan hubungan birokratik. Artinya, berzakat dan tidak berzakat pada Bapelazis akan mempunyai dampak yang berbeda terhadap nasib karir -atau setidaknya mempengaruhi kinerja- yang bersangkutan di lingkungan dinasnya tersebut.

Pada Bapelazis tidak ada konsepsi dan strategi khusus dalam rangka mensukseskan usahanya. Semuakonsep dan strategi perzakatan yang diambil bersifat konvensional. Kalaupun ada yang sedikit tidak konvensional barangkali adalah model pembayaran zakatnya yang dipotongkan dari gaji tiap bulan. Dan, inilah salah satu alasan banyak guru

\footnotetext{
${ }^{41}$ Ibid., hal. 5.
} 
dan pegawai menolak menjadi muzakki. Sementara bagi eksponen Bapelazis dan mereka yang menjadi muzakki, cara seperti itu hanyalah sebuah siasat (iguh : Jawa) untuk mempermudah pembayarannya. Dasar pemikirannya adalah daripada gaji habis setiap bulan sehingga pada akhir tahun merasa kesulitan membayar atau merasa enggan setelah melihat nominal zakatnya secara kumulatif, maka pemotongan tiap bulan bisa diartikan sebagai cicilan zakat atau setidaknya nabung untuk zakat. Toh masalah absah tidaknya zakat tidak bergantung pada adanya penyerahan secara formal. Justru yang paling menentukan adalah faktor niat dan komitmen.

b.Pendistribusian dan Pendayagunaan zakat

Dalam hal penyaluran dana zakat ini hampir tidak ada perbedaan antara Bapelurzam dan Bapelazis. Kedua lembaga amil zakat itu mengikuti pola penyaluran zakat ala poendistribusian dan ala pendayagunaan sekaligus, membagi para mustahiq menjadi kelompok dlu'afa dan kelompok sabilillah pada satu sisi dan pada sisi yang lain menjadi kelompok perorangan dan kelompok lembaga, menyelenggarakan musyawarah dalam menentukan pos penyaluran dan mustahiq, dan lain-lain. Namun di samping itu, karena faktor spesifikasi lembaga kedua organisasi pengeloal zakat itu juga mempunyai ciri masing-masing yang tidak dimiliki oleh yang lain.
Bagian dana zakat untuk kelompok dlu'afa lebih dari 50 persen (yakni 53 persen pada tahun $1424 \mathrm{H}$ dan 54,5 persen pada tahun $1425 \mathrm{H}$ ) dan bagian dana zakat untuk kelompok sabilillah adalah kurang dari 50 persen (yakni 47 persen tahun $1424 \mathrm{H}$ dan 45,5 persen tahun $1425 \mathrm{H}$ ). Selisih antara kedua kelompok tersebut adalah antara 6 sampai 9 persen. Namun demikian boleh dibilang bahwa kedua pola pembagian itu masih mendekati pola fifty-fifty yang berarti bahwa kondisi sosial ekonomi pada dua tahun berjalan ini menurut penilaian Bapelurzam adalah normal.

Hingga di sini apa yang ambil oleh pengurus Bapelurzam pada dua tahun zakat tersebut sesuai dan tidak menyimpang dari pedoman praktis. Namun selanjutnya tidak demikian. Bagian fakir miskin yang diberikan secara produktif pada tahun $1424 \mathrm{H}$ hanya Rp 13.776.750,(tiga belas juta tujuh ratus tujuh puluh enam ribu tujuh ratus lima puluh rupiah) atau hanya 14,1 persen dari keseluruhan bagian fakir miskin sebesar Rp. 97.626.750,- (sembilan puluh tujuh juta enam ratus dua puluh enam tujuh ratus lima puluh rupiah). Kemudian dari keseluruhan bagian fakir miskin sebesar Rp. 118.553.750,- (seratus delapan belas juta lima ratus lima puluh tiga ribu tujuh ratus lima puluh rupiah) pada tahun zakat $1425 \mathrm{H}$ yang ditasharrufkan secara produktif hanya Rp. 10.003.750,- (sepuluh 
juta tiga ribu tujuh ratus lima puluh rupiah) atau 8,4 persen. Ini jelas sangat "menyimpang" dari petunjuk yang "ditetapkan" sebagaimana dikemukakan di atas pun pula jauh dari semangat memberdayakan masyarakat ekonomi lemah.

Memang dana zakat bagian fakir miskin produktif telah cukup banyak yang merupakan kumulatif dari tahun-tahun sebelumnya, karena berstatus "pinjaman modal" bagi fakir miskin. Sehingga dari tahun ke tahun selalu bertambah. Hanya saja pengelolaan dana zakat produktif itu tidak dilaksanakan oleh Bapelurzam tetapi Majlis Ekonomi Pimpinan Cabang Muhammadiyah. Bapelurzam hanya menentukan besamya dan kemudian secara penuh menyerahkannya kepada Pimpinan Cabang Muhammadiyah yang selanjutnya didelegasikan kepada Majlis Ekonomi. Karena itu mengenai besarnya angka dana zakat produktif pada saat ini, siapasiapa saja yang menjadi mustahiq, berapa mustahiq yang telah dientaskan secara ekonomi dari program zakatnya ini, dan sebagainya tidak masuk dalam laporan pertanggung jawaban Bapelurzam. Sehingga di sini ada kesan "tertutup" dan tidak transparan, suatu kondisi yang sangat dicela dan ingin dihindari oleh Bapelurzam. ${ }^{42}$

\footnotetext{
${ }^{42}$ Ketiadaan informasi ini karena penulis tidak pernah berpikir bahwa mekanismenya terpisah seperti tersebut. Ketika penulis bertemu dengan para tokoh Bapelurzam pada tanggal 4 Juni 2005 guna wawancara, Ketua Majlis Ekonomi Pimpinan Cabang Muhammadiyah tidak hadir dalam forum
}

Mekanisme penyaluran zakat seperti tersebut di atas juga diterapkan oleh Bapelazis. Hanya saja Bapelazis tidak "memaksakan" penyaluran pada delapan ashnaf konvensional tetapi mencukupkan secara permanen pada lima saja, yaitu fakir, miskin, amil, sabilillah dan ibnu sabil. $^{43}$ Barangkali, menurut Bapelazis, tidak semua ashnaf itu ada pada saat ini. Golongan riqab, gharim, dan muallaf dengan segala variasinya masing-masing sulit didapatkan pada kondisi sekarang.

\section{Faktor-faktor yang Mempengaruhi} Penggalian Potensi Zakat di Kabupaten Kendal

\section{a. Faktor Penunjang}

Beberapa hal berikut merupakan faktor-faktor penunjang penggalian potensi zakat di Kabupaten Kendal. Pertama, faktor pribadi pengelola zakat yang dalam hal ini berkaitan dengan pemberian contoh berzakat dan sikap militansi. Kedua, faktor dukungan dari yang punya "wewenang atau kuasa". Ketiga, faktor wajib zakat yang dalam hal ini berkaitan dengan tingkat kesadaran berzakat dan kepercayaan terhadap pengelola.

tersebut. Sementara mereka yang hadir, yaitu H. Muslim, H. Rubaidi, H. Su'ud Nasroh dan H. Solikhin tidak bisa memberikan penjelasan secara detail.

${ }^{43}$ Wawancara dengan Drs. H. khairuddin, M.Si. dan Laporan Pertanggung Jawaban Bapelazis Periode 2001-2004. 


\section{b. Faktor Penghambat}

Kecuali faktor penunjang, ada juga beberapa faktor yang menghambat penggalian potensi zakat di Kabupaten Kendal. Bahkan baik dari segi kualitas maupun kuantitas, faktor-faktor penghambat itu jauh lebih besar dan beraneka ragam macamnya. Pertama, faktor pengelola yang dalam hal ini berkaitan dengan tingkat militansi yang rendah dan minimalnya jumlah personal. Kedua, faktor penguasa dan pihak yang punya wewenang, baik penguasa dalam artian politis sebagaimana terjadi pada BAZ maupun bukan politis seperti pada Lazis NU. Yang diamksud di sini tidak adanya komitmen dan visi pengelolaan zakat apda mereka. Ketiga, faktor wajib zakat yang dalam hal ini berkaitan dengan pemahaman yang minim tentang zakat. Keempat, faktor tokoh masyarakat/kiyahi dalam artian sebagai tokoh yang berpengaruh terhadap masyarakat sebagian besar dari mereka masih berpikiran konserfatif terutama berkenan dengan obyek zakat. Kelima, faktor kelembagaan dan biaya operasional organisasi pengelola zakat.

\section{Potensi Zakat sebagai Pilar} Perekonomian di Kabupaten Kendal Dana zakat yang terkumpul dan dikelola oleh Bapelurzam dan Bapelazis Pada tahun 2004 sejumlah Rp. 759.851.369,(tujuh ratus lima puluh sembilan juta delapan ratus lima puluh satu ribu tiga ratus enam puluh sembilan rupiah) hampir tidak ada artinya bila dibandingkan dengan jumlah keluarga yang berhak mendapatkan bagian zakat di Kabupaten Kendal yang jumlahnya mencapai 125.483. Apalagi dari dana zakat yang terkumpul itu tidak seluruhnya ditasharrufkan untuk pemberdayaan masyarakat ekonomi lemah dalam artian pemberian secara produktif. Namun demikian tidak dengan serta merta dapat diartikan bahwa potensi zakat sebagai pilar perekonomian umat di Kabupaten Kendal tidak ada atau nihil, tidak. Persoalannya tidak sesederhana itu. Ada banyak hal terkait yang tidak bisa diabaikan untuk dapat mengambil kesimpulan secara tepat. Pertama, secara riil badan/lembaga pengelola zakat di Kabupaten Kendal tidak hanya Bapelurzam dan Bapelazis. Benar hanya kedua badan/ lembaga pengelola zakat tersebut yang lingkup kerjanya meliputi wilayah Kabupaten Kendal, akan tetapi di sana banyak sekali terdapat badan/lembaga pengelola zakat yang dapat bekerja secara aktif meskipun keberadaannya tidak semuanya bersifat permanen dan lingkup kerjanya relatif sempit sebatas satu desa/kelurahan, misalnya. Dengan demikian dapat diasumsikan bahwa dana zakat yang terkumpul dan dikelola oleh keseluruhan badan/lembaga pengelola zakat yang ada tentu lebih besar lagi dari yang dikumpulkan dan dikelola oleh Bapelurzam dan Bapelazis. 
Kedua, kalaupun toh, misalnya, jumlah badan/lembaga pengelola zakat yang beroperasi di Kabupaten Kendal terbatas, sekali lagi, tidak serta merta dapat diartikan bahwa potensi zakat di Kabupaten Kendal nihil. Sebab, dari 67 wajib zakat yang menjadi responden 49 orang atau 73 persen diantaranya telah membayar zakatnya secara kontinyu setiap tahun. Kemudian dari sejumlah itu hanya 1 orang atau 1,5 persen saja yang menyerahkan zakatnya pada lembaga/ badan pengelola zakat, sedangkan lainnya sejumlah 48 orang atau 71,6 persen membayarkannya secara langsung kepada para mustahiq. Berikut ini beberapa tabel tentang wajib zakat di Kabupaten Kendal.

\section{Tabel 1}

Wajib Zakat di Kabupaten Kendal yang Sudah Maupun Belum Menunaikan Zakatnya

\begin{tabular}{|c|c|c|c|c|}
\hline NO & $\begin{array}{l}\text { PELAKS. } \\
\text { ZAKAT }\end{array}$ & $\begin{array}{l}\text { WAJBB } \\
\text { ZAKAT }\end{array}$ & $\%$ & KETERANGAN \\
\hline 1 & Sudahrutin & 49 & 73 & \multirow{5}{*}{$\begin{array}{l}\text { * Wajib zakat yang } \\
\text { belum bezzakat itu terdiri } \\
\text { dari mereka yang secara } \\
\text { elssplisit mengaku belum } \\
\text { berzakat dan mereka } \\
\text { yang menjawab hanya } \\
\text { mengeluarkan zakat } \\
\text { fitrah sebesar } 2,5 \mathrm{~kg} \\
\text { beras }\end{array}$} \\
\hline 2 & $\begin{array}{l}\text { Kadang- } \\
\text { kadang }\end{array}$ & 3 & 4,5 & \\
\hline 3 & Belum* & 14 & 21 & \\
\hline 4 & Diam & 1 & & \\
\hline & Jumlah & 67 & 100 & \\
\hline
\end{tabular}

Dari tabel tersebut dapat dipahami bahwa mayoritas wajib zakat di
Kabupaten Kendal telah menunaikan zakatnya. Bila secara keseluruhan jumlah wajib zakat di Kabupaten Kendal ada 119.141 orang, maka berarti ada sekitar 86.973 orang yang telah menunaikan kewajiban zakatnya. Angka 119.141 adalah jumlah keluarga di Kabupaten Kendal yang masuk dalam kategori sejahtera I, sejahtera II, sejahtera III dan sejahtera III plus ${ }^{44}$

Tabel 2

Wajib Zakat (Muzakki) di Kabupaten Kendal Berdasarkan Besaran Zakat yang Dibayarkan Tahun 2004

\begin{tabular}{|c|c|c|c|c|}
\hline No & BESARANZAKAT & MUZAKKI & $\%$ & KETERA \\
\hline 1 & 50.000 & 3 & 6,12 & \multirow{12}{*}{ 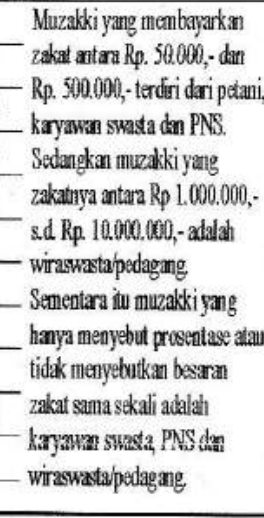 } \\
\hline 2 & s.d.Rp. $\quad 100.000,-$ & 3 & 6,12 & \\
\hline 3 & s.d.Rp. $\quad 200.000,-$ & 8 & 16,33 & \\
\hline 4 & s.d. Rp. $\quad 300.000,-$ & 6 & 12,24 & \\
\hline 5 & $400.000,-$ & - & - & \\
\hline 6 & sd. Rp. $\quad 500.000,-$ & 2 & 4,08 & \\
\hline 7 & s.d. Rp. $1.000 .000,-$ & 3 & 6,12 & \\
\hline 8 & s.d. Rp. $\quad 5.000 .000,-$ & 1 & 2,04 & \\
\hline 9 & s.d. Rp. 10.000 .000 ,- & 1 & 2,04 & \\
\hline 10 & Menyebut prosentase & 19 & 38,78 & \\
\hline 11 & Tdk menyebutkan & 3 & 6,12 & \\
\hline & IIIMLAH & & II & \\
\hline
\end{tabular}

Bila angka-angka itu dimasukkan dalam perhitungan jumlah wajib zakat yang telah menunaikan zakatnya (muzakki) sebesarnya 86.973 orang dan untuk muzakki yang tidak menyebutkan zakatnya dianggap membayar dalam perhitungan minimal yakni Rp. 50.000,- (lima puluh ribu rupiah), maka

\footnotetext{
${ }^{44}$ Lihat catatan kaki nomor 16 bab ini.
} 
jumlah dana zakat yang telah dibayarkan di Kabupaten Kendal adalah sebagai berikut

Tabel 3

Perhitungan Dana Zakat di Kabupaten Kendal Tahun 2004

\begin{tabular}{|c|c|c|c|}
\hline No & BESARANZAKAT & MUZAKKI & $\begin{array}{c}\text { ZAKAT } \\
\text { TERKUMPUL }\end{array}$ \\
\hline 1 & $50.000,-$ & $51,02 \% \times 86.973=35.676$ & Rp. 2.218 .650 .000 . \\
\hline 2 & 100.000 & $6,12 \% \times 86.973=5.322$ & Rp. $\quad 532.200 .000,-$ \\
\hline 3 & 200.000 & $16,33 \% \times 86.973=14.202$ & 2.840 .400 .000 \\
\hline 4 & 300.000 & $12,24 \% \times 86.973=10.645$ & 3.193.500.000,- \\
\hline 5 & $400.000,-$ & 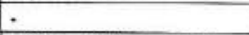 & \\
\hline 6 & s.d. Rp. $\quad 500.000$,- & $4,08 \% \times 86.973=3.548$ & Rp. $\quad 1.774 .000 .000$, \\
\hline 7 & s.d. Rp. 1.000 .000 ,- & $6.12 \% \times 86.973=5.322$ & 5.322 .000 .000 \\
\hline 8 & s.d. Rp. $\quad 5.000 .000$,- & $2,04 \% \times 86.973=1.774$ & Rp. $\quad 8.870 .000 .000,-$ \\
\hline \multirow[t]{2}{*}{9} & s.d. Rp. $10.000 .000,-$ & $2,04 \% \times 86.973=1.774$ & Rp. $17.740 .000 .000,-$ \\
\hline & Jumlah & & Rp. 42.490 .750 .000 , \\
\hline
\end{tabular}

dari tabel di atas terlihat bahwa dana zakat yang telah dibayarkan oleh para wajib zakat di Kabupaten Kendal tahun 2004 adalah Rp. 42.490.750.000,- (empat puluh dua milyar empat ratus sembilan puluh juta tujuh ratus lima puluh ribu rupiah). Angka tersebut sungguh fantastis dan jauh lebih tinggi dari PAD Kabupaten Kendal tahun 2004 yang hanya Rp. 31.893.476.543,- (tiga puluh satu milyar delapan ratus sembilan puluh tiga juta empat ratus tujuh puluh enam ribu lima ratus empat puluh tiga rupiah). Dan perlu diingat bahwa angka tersebut didapat dengan menganggap 44,9 persen atau 39.050 muzakki yang hanya menyebutkan prosentase zakat yang dikeluarkannya atau tidak menyebutkan sama sekali sebagai hanya mengeluarkan zakat dalam hitungah minimal, yaitu sebesar Rp. 50.000,- (lima puluh ribu rupiah). Jika tidak demikian, tentu dana zakat yang telah dibayarkan akan jauh lebih besar lagi. Padahal, seperti tersebut dalam tabel 18 , muzakki yang menyebutkan zakat yang dikeluarkan hanya dalam jumlah prosentase dari penghasilan atau tidak menyebutkan sama sekali adalah muzakki kelompok karyawan swasta, PNS dan wiraswasta/ pedagang yang di lain pihak merupakan kelompok pembayar zakat dengan besaran antara Rp. 1.000.000,- (satu juta rupiah) sampai Rp. 10.000.000,- (sepuluh juta rupiah). ${ }^{45}$

Ketiga, arti zakat sebagai pilar perekonomian umat tidak hanya sebatas pada kondisi ketika dana zakat yang berhasil dikelola oleh badan/lembaga pengelola zakat pada suatu waktu mencapai angka yang tinggi dan demikian pula dana yang dialokasikan untuk pemberdayaan masyarakat ekonomi lemah mencapai jumlah yang signifikan. Tidak, sekali-kali tidak. Makna zakat sebagai

${ }^{45}$ Memang harus diakui bahwa keadaan yang sebenarnya tidak mesti bersifat matematis seperti itu karena ada variabel lain atau sebut saja faktor $X$ yang berpengaruh dan menentukan. Yaitu faktor tingkat keberagamaan (baca: penghayatan dan pengamalan serta ketaatan terhadap ajaran agama). Maksudnya, bahwa boleh jadi wajib zakat yang ada di luar Kecamatan Ngampel, Patebon dan Kendal tidak sama tingkat keberagamaannya dengan wajib zakat yang ada di wilayah tiga kecamatan yang menjadi sampel tersebut. Tetapi, bagaimanapun, hasil penelitian ini setidaknya telah memberikan gambaran akan besarnya dana zakat yang telah dibayarkan oleh para wajib zakat di Kabupaten Kendal. 
pilar perekonomian umat, seperti telah dikemukakan pada bab terdahulu, setidaknya mencakup tiga hal :

1. Distribusi pendapatan;

2. Pemberdayaan ekonomi masyarakat ekonomi lemah; dan

3. Peningkatan investasi dan terciptanya lapangan pekerjaan. ${ }^{46}$

Fungsi pertama telah secara otomatis ada dan senantiasa melekat pada zakat dari zaman dahulu hingga kapanpun. Baik dana zakat dikelola oleh badan/lembaga pengelola zakat maupun diserahkan oleh para muzakki secara langsung kepada para mustahik distribusi pendapatan telah terjadi. Fungsi kedua hanya bisa efektif apabila dana zakat dikelola oleh badan/ lembaga pengelola zakat. Walaupun dana zakat yang telah dibayarkan oleh para wajib zakat mencapai jumlah yang sangat tinggi, apabila dana tersebut oleh para muzakki diserahkan secara langsung kepada para mustahik maka sulit dikatakan telah terjadi pemberdayaan masyarakat ekonomi lemah. Demikian pula bila penyaluran dana zakat oleh badan/lembaga pengelola zakat masih lebih mengutamakan pada dlu'afa konsumtif daripada dlu'afa produktif, maka pemberdayaan belum terealisir. Sementara itu fungsi ketiga bisa terjadi selama umat Islam yang

\footnotetext{
${ }^{46}$ Baca Bab II terutama pada sub bab potensi zakat sebagai pilar perekonomian umat.
}

mampu telah menunaikan zakatnya baik diserahkan secara langsung kepada para mustahik atau dipercayakan kepada badan/ lembaga pengelola zakat. Namun fungsi terakhir ini akan lebih efektif apabila dana zakat dikelola oleh badan/lembaga pengelola zakat dan lebih memprioritaskan pada dlu'afa produktif.

Dalam kalimat yang lain dapat dikemukakan bahwa pemaknaan terhadap potensi zakat sebagai pilar perekonomian umat bisa dilakukan secara langsung maupun tidak langsung. Pemaknaan secara langsung terkait dengan fungsi ekonomis yang kedua dari zakat, sedangkan pemaknaan secara tidak langsung terkait dengan fungsi pertama dan ketiga. Dengan demikian boleh dikatakan bahwa zakat telah menjadi suatu pilar perekonomian umat di Kabupaten Kendal.

Keempat, upaya pemberdayaan masyarakat ekonomi lemah melalui pengelolaan dana zakat oleh badan/lembaga pengelola zakat memerlukan waktu, tidak sekali selesai. Maksudnya, betapapun besarnya dana zakat yang berhasil dikumpulkan dan dikelola oleh badan/ lembaga pengelola zakat pada suatu waktu mustahil dapat langsung menghilangkan kemiskinan dari masyarakat. Kemiskinan tidak dapat dihilangkan, tetapi hanya mungkin dikurangi. Karena itu yang diperlukan adalah upaya serius dan terus menerus untuk sampai batas maksimal. 
F. Kesimpulan

1. Penggalian potensi zakat oleh badan/ lembaga pengelola zakat di Kabupaten Kendal mencakup tiga aktifitas, yaitu pengumpulan dana zakat, pendistribusian dan pendayagunaan. Pertama, dalam upaya memaksimalkan hasil pengumpulan zakat diformulasikan suatu konsep perzakatan "progresif" dan ditempuh suatu langkah dan strategi yang juga 'progresif' sebagaimana yang dilakukan oleh Bapelurzam. Atau dengan memakai konsep dan strategi perzakatan sedikit konvensional dengan menggunakan "bantuan" birokratik berbau sedikit "paksaan" seperti yang terjadi di Bapelazis. Sistem administrasi yang tertib dan transparan juga ditempuh. Pembuatan laporan pengelolaan zakat adalah suatu nilai plus tersendiri karena yang demikian telah dapat menumbuhkan kepercayaan masyarakat, terutama muzakki terhadap lembaga/badan pengelola zakat. Satu hal lagi adalah pemberian contoh dan suri tauladan berzakat dari para tokoh dan pribadi para pengelola zakat. Kedua, penyaluran zakat dilakukan dalam bentuk pendistribusian dan pendayagunaan. Pendistribusian zakat dimakusdkan sebagai penyaluran dana zakat kepara mustahiqnya secara konsumtif. Sedang pendayagunaan zakat dimaksudkan sebagai penyaluran zakat secara produktif. Tasharruf secara konsumtif dialokasikan pada semua kelompok mustahiq, termasuk fakir miskin. Sedang tasharruf secara produktif hanya dialokasikan pada kelompok fakir miskin dengan kriteria tertentu. Penyaluran dana zakat menekankan pada kelangsungan hidup fakir miskin, pemberdayaan ekonomi lemah dan pembinaan umat Islam yang dalam ashnaf zakat inheren pada kelompok fakir miskin konsumtif maupun produktif dan sabilillah.

2. Ada sejumlah faktor yang mempengaruhi pengelolaan zakat di Kabupaten Kendal, yang dapat dikategorikan sebagai faktor penunjang dan faktor penghambat. Karena ada empat badan/lembaga pengelola zakat yang menjadi obyek penelitian ini, maka bisa terjadi satu faktor merupakan penunjang bagi badan/lembaga pengelola zakat yang satu dan pada saat yang bersamaan juga sekaligus sebagai penghambat bagi badan/lembaga pengelola zakat yang lain. Faktorfaktor penunjang pengelolaan zakat adalah faktor pribadi pengelola zakat, faktor dukungan dari pihak yang punya wewenang atau kuasa, dan faktor wajb zakat sendiri. Sedangkan 
Jurnal Law Reform

Volume 2, Nomor 2, Tahun 2007
Program Studi Magister Ilmu Hukum Fakultas Hukum Universitas Diponegoro faktor-faktor yang menghambat pengelolaan zakat meliputi faktor pengelola, faktor penguasa dan yang punya wewenang, faktor wajib zakat, faktor tokoh masyarakat/kiyahi, dan faktor kelembagaan dan biaya operasional organisasi pengelola zakat.

3. Minimnya dana zakat yang berhasil dikumpulkan dan dikelola oleh badan/ lembaga pengelola zakat di Kabupaten Kendal tidak serta merta dapat diartikan bahwa potensi zakat sebagai pilar perekonomian umat bersifat nihil. Ada beberapa faktor terkait yang justru mengindikasikan bahwa zakat telah menjadi salah satu pilar perekonomian di Kabupaten Kendal.

\section{G. Daftar Pustaka}

Al-'Asqalaniy, Al-Hafidz Ibn Hajar, Bulugh alMaram min Adillah al-Ahkam, Indonesia : Dar Ihya al-Kutub al-'Arabiyyah, t.t. Al-'Assal, Ahmad Muhammad dan Fathi Ahmad Abdul Karim, Sistem, Prinsip dan Tujuan Ekonomi Islam, terjemahan H. Imam Saefudin, cetakan I, Bandung : CV. Pustaka Setia, 1999.

Al-Andalusiy, al-Imam al-Qadhi Abu al-Walid Muhammad bin Ahmad bin Ahmad Bin Rusyid al-Qurthubi, Bidayah al-Mujtahid wa Nihayah al-Muqtashid, Juz I, ttp.

Dar al-Fikr, t.t.

Al-Dimyati, al-Sayyid Abi Bakr bin al-Sayyid Muhammad Syatha, l'anah al-Thalibin, Juz II, Semarang : Maktabah wa Mathba'ah Thoha Putra, t.t.

Ali, M. Daud dan Daud, Habibah, Lembagalembaga Islam di Indonesia, cetakan I, Jakarta : PT. Raja Grafindo Persada, 1995.

Al-Jaziriy Abdurrahman, Al-Fiqh 'ala al-Madzahib al-Arba'ah, Juz II, Istambul Turki : Maktabah al-Haqiqah, 1986.

Al-Nuriy, Sulaiman, Ibanah al-Ahkam Syarh Bulugh al-Maram, Juz II, Bairut : Dar al-Tsaqafah al-Islamiyyah, t.t.

Al-Qur'an al-Karim

Anggaran Dasar Bapelazis Depag Kendal.

Anggaran Rumah Tangga Bapelazis Depag Kendal.

Anggaran Rumah Tangga Nahdlatul Ulama.

Badan Pelaksana Urusan Zakat Muhammadiyah (Bapelurzam) Cabang Weleri, Laporan Pengelolaan Zakat Amwal Periode XXVII Tahun 1425 H/2005 M

Hadi, Sutrisno, Metodologi Research, Jilid I, Cetakan X (Yogyakarta : Yayasan Penerbitan Fakultas Psikologi UGM, 1980. Lembaga Amil Zakat "Badan Pelaksana Urusan Zakat Zakat Muhammadiyah" (Bapelurzam) Daerah kendal, Laporan Zakat Tahun $1425 \mathrm{H}$.

Mannan, M. Abdul, Teori dan Praktek Ekonomi Islam, terjemahan M. Nastangin, 
Jurnal Law Reform

Volume 2, Nomor 2, Tahun 2007
Program Studi Magister Ilmu Hukum Fakultas Hukum Universitas Diponegoro
Yogyakarta : PT. Dana Bhakti Wakaf, 1997.

Masjfuk Zuhdi, Masail Fiqhiyah, Edisi II Cetakan

II, Jakarta : CV Haji Masagung, 1991.

Muhajdir, Noeng, Metodologi Penelitian Kualitatif,

edisi III, cetakan 8, Yogyakarta : Rake

Sarasin, 1998.

Petunjuk Pelaksanaan Pembinaan Lembaga

Pengelola Zakat, Jakarta : Direktorat Pengembangan Zakat dan Wakaf Direktorat

Jenderal Bimbingan Masyarakat Islam dan Urusan Haji, 2003.

Qardhawi, Qardhawi, Hukum Zakat : Studi Komparatif mengenai Status dan Filsafat Zakat Berdasarkan Qur'an dan Hadis, terjemahan Salman Harun, dkk., cetakan 6, Jakarta : PT. Pustaka Litera AntarNusa, 2002.

Rahman, Afzalur, Doktrin Ekonomi Islam, Jilid III, terjemahan Soeroso dan Nastangin, cetakan II, Yogyakarta : PT. Dana Bhakti Prima Yasa, 2002.

Ritzer, George, Sosiologi IImu Pengetahuan Berparadigma Ganda, Alimandan (Penyadur), Jakarta : Rajawali Pers, 1992.

Surat Keputusan Kepala Kantor Departemen Agama Kabupaten Kendal Nomor Mk.04/ 1.b/Kp.08.4/1254/1995 perihal Pembentukan Bapelazis Kandepag Kabupaten Kendal Wignyosoebroto, Soetandyo, "Keragaman dalam Konsep Hukum, Tipe Hukum dan Metode Penelitiannya", makalah disampaikan Pelatihan Peneliti Tenaga Edukatif IAIN
Walisongo tanggal 1 Oktober s/d 27 Desember 1996.

Yafie, "Islam dan Problema Kemiskinan", Pesantren, No. 2, Vol. III, Tahun 1986. Yafie, Ali, Menggagas Fiqih Sosial, cetakan 2, Bandung : Mizan, 1994.

Zakat Kita Zakat Terapan Buku I, Kendal : Pengurus Daerah Muhammadiyah Kabupaten Kendal, 1999. 